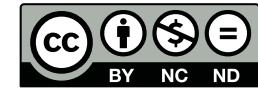

Estudos Teológicos foi licenciado com uma Licença Creative Commons Atribuição - NãoComercial - SemDerivados 3.0 Não Adaptada

http://dx.doi.org/10.22351/et.v57i1.2988

\title{
Hermenêutica do espírito: a Leitura bíblica Na Reforma RAdicAL ${ }^{1}$

\author{
Hermeneutics of the Spirit: \\ biblical reading in Radical Reformation
}

\section{Kenner Roger Cazotto Terra ${ }^{2}$ David Mesquiati de Oliveira ${ }^{3}$}

Resumo: Este texto reflete sobre os insights da Reforma Radical sobre a leitura da Bíblia como parte da grande Reforma da igreja cristã. Esse patrimônio nem sempre foi valorizado, seja porque foi invisibilizado por falta de pesquisas (política), por ser o tema considerado não relevante (opção teológica), porque esses grupos foram estigmatizados como cismáticos e sectários (leitura parcial) ou por ignorância. Contudo, desde o século XX renovou-se a pesquisa sobre esses grupos, bem como houve um amadurecimento ecumênico na convivência entre as diferentes igrejas oriundas dos diversos ramos da Reforma, que permite uma aproximação mais positiva a esses sujeitos e movimentos históricos. O texto aponta que a forma como a Reforma Radical lia as Escrituras não pode ser preterida e relegada como algo ultrapassada, mas deveria ser revisitada e refletida de forma mais acurada.

Palavras-chave: Reforma Radical. Espiritualistas. Leitura bíblica. Pneumatologia.

Abstract: This text reflects on the insights of the Radical Reformation about reading the Bible as part of the great Reformation of the Christian church. This patrimony was not always valued, either because it was invisible due to lack of research (policy), because the theme was not considered relevant (theological option), because these groups were stigmatized as schismatic and sectarian (partial reading) or ignorance. However, the research on these groups has been renewed since the twentieth century, as well as an ecumenical maturation in the coexistence between the different churches from the

1 O artigo foi recebido em 29 de março de 2017 e aprovado em 12 de maio de 2017 com base nas avaliações dos pareceristas ad hoc.

2 Doutor em Ciências da Religião (UMESP), docente do Programa de Pós-Graduação em Ciências das Religiões da Faculdade Unida de Vitória (UNIDA), pesquisador no Grupo RELEP Brasil (Rede Latino-Americana de Estudos Pentecostais), do Grupo Oracula de pesquisa, da ABIB (Associação Brasileira de Interpretação Bíblica), e BAAS (The Bible Across the Americas Seminar). Contato: kenner@faculdadeunida.com.br

3 Doutor em Teologia (PUC-Rio), docente do Programa de Pós-Graduação em Ciências das Religiões da Faculdade Unida de Vitória (UNIDA) e pesquisador no Grupo RELEP Brasil (Rede Latino-Americana de Estudos Pentecostais). Contato: david@faculdadeunida.com.br 
various branches of the Reformation, which allows a more positive approximation to these subjects and historical movements. The text points out that the way the Radical Reformation read the Scriptures cannot be overlooked and relegated as outdated, but should be revisited and reflected more sharply.

Keywords: Radical Reformation. Spiritualists. Bible reading. Pneumatology.

\section{Introdução}

O movimento da Reforma do século XVI envolveu uma complexidade de fatores políticos, sociais e culturais. Mas, sobretudo, como afirma Timothy George, a Reforma é uma iniciativa religiosa, movida por interesses teológicos. A Reforma "foi um tempo de reavivamento e revolução". E prossegue: “a época da Reforma produziu mais mártires do que as perseguições na igreja primitiva"4. Walter Altmann acrescenta que, considerando o contexto social de cristandade da época, qualquer movimento reformatório, necessariamente, teria que passar pela transformação da igreja. Ao dirigir-se à igreja com suas críticas, Lutero ajudou a sedimentar as mais variadas críticas ao sistema medieval que resistia aos novos tempos. ${ }^{5}$ Mas esse movimento não pode ficar restrito a um segmento específico. A Reforma deve ser entendida, mesmo em seu aspecto teológico, a partir dos diferentes grupos envolvidos. George Williams classificou a Reforma Protestante em dois grupos principais, ao que chamou de Reforma $\mathrm{Ma}$ gisterial (luterana, calvinista e anglicana) e Reforma Radical (anabatistas, espiritualistas e racionalistas). ${ }^{6}$ Ao mesmo tempo, não se podem desconsiderar os movimentos reformatórios dentro da Igreja Católica. Assim, convocar as diferentes igrejas para refletir à luz dos 500 anos da Reforma deveria contemplar a dinâmica dos diferentes grupos daquele tempo. Este texto busca refletir sobre os insights da Reforma Radical como parte da grande Reforma da igreja cristã. ${ }^{7}$

\section{A Reforma Protestante}

O ano de 2017 será marcado em muitos lugares e espaços pela celebração dos 500 anos do movimento chamado de "Reforma Protestante". Lutero e os demais reformadores foram, sem dúvida, grandes personalidades que estiveram envolvidas no início daquele movimento. No entanto, como é comum nas grandes narrativas, os reformadores, vez ou outra, são tratados como "mártires sem sacrifício" que lideraram

\footnotetext{
GEORGE, Timothy. Teologia dos reformadores. São Paulo: Vida Nova, 1994. p. 20s.

Cf. ALTMANN, Walter. Lutero e libertação. São Leopoldo: Sinodal; São Paulo: Ática, 1994. p. 30.

6 WILliAMS, George H. La Reforma Radical. México: Fondo de Cultura Económica, 1983. p. 3.

7 Timothy George afirmou: “Os teólogos contemporâneos fariam bem em ouvir novamente a mensagem desses cristãos corajosos que desafiaram imperadores e papas, reis e câmaras municipais, porque suas ideias estavam cativas à Palavra de Deus" (GEORGE, Timothy. Teologia dos reformadores. São Paulo: Vida Nova, 1994. p. 11).
} 
uma "revolução". Mas, sabemos, depois de publicações especializadas ${ }^{8}$, que os movimentos europeus de 1517 em diante poderiam ser chamados de "brumas" - como diriam os historiadores que pensam a história em longa duração ${ }^{9}-$ de desenvolvimentos estruturais mais "de baixo", o que impede hipervalorização de figuras emblemáticas. Como bem defende Le Goff, para explicar a Nova História Cultural, "a Nova História mostra que esses 'grandes acontecimentos' são em geral apenas a nuvem - muitas vezes sangrenta - levantada pelos verdadeiros acontecimentos sobrevindos antes desses, isto é, as mutações profundas da história"10.

Antes de Lutero temos, por exemplo, os Goliardos, que carnavalizavam - para usar um conceito de M. Bakhtin ${ }^{11}$ - a igreja oficial com indisciplinas e sátiras. Como andarilhos mendicantes, criticavam asperamente as estruturas sociais e poetizavam o vinho, o jogo e o amor, acirrando os ânimos mais piedosos. ${ }^{12} \mathrm{O}$ alvo das mais duras críticas desses transeuntes, vistos como repugnantes, era a tríade papa, bispo e monge. Le Goff afirma que

A inspiração anti-pontifícia e anti-romana dos goliardos mistura-se sem se confundir com duas outras correntes: a corrente gibelina, que ataca sobretudo as pretensões temporais do papado e apóia o Partido do Império contra o do Sacerdote; a corrente moralizadora, que critica no pontífice e na corte de Roma os compromissos com o século, o luxo, o gosto do dinheiro. [...] O bestiário satírico dos goliardos, no espírito do romance grotesco, desenvolve uma linha de eclesiásticos metamorfoseados em animais e faz surgir no frontão da sociedade um mundo de carrancas eclesiásticas. [...] Há mais nesses ataques do que as brincadeiras, tradicionais, sobre seus maus costumes: gula, preguiça, devassidão. Há espírito secular - próximo do espírito leigo - denunciador dos monges como concorrentes que arrancam dos pobres párocos prebendas, penitentes, fieis $[\ldots]^{13}$.

Antes de Lutero, Guilherme de Ockham já dizia que a moralidade do ser humano não depende da sua própria ação, mas da aceitação da vontade de Deus e sua graça, que pode santificar antes que haja o arrependimento. Além disso, em seu Brevilóquio Sobre o Principado Tirânico, Ockham já questionava o poder papal e a tradição:

8 Por exemplo, BLOCH, E. Tomás Müntzer: teólogo da revolução. Rio de Janeiro: Tempo Brasileiro, 1973.

9 A Nova História Cultural tem como projeto historiográfico a história total, das mentalidades, imaginários, a micro-história etc. Essa historiografia propõe a compreensão dos movimentos sociais e culturais da humanidade em uma perspectiva de longa duração, o que impede de colocar no centro dos acontecimentos grandes datas e nomes, redirecionando o olhar para a vida cotidiana, os pequenos feitos e a fluidez das identidades. Cf. BURKE, Peter. Origens da história cultural. Variedades de história cultural. São Paulo: Civilização Brasileira, 2006; BURKE, Peter. O que é história cultural? Rio de Janeiro: Zahar, 2008; PESSAVENTO, Sandra. História e linguagens. Rio de Janeiro: 7 Letras, 2006; RIOUX, Jean-Pierre; SIRINELLI, Jean-François (Orgs.). Para uma história cultural. Lisboa: Estampa, 1998; LE GOFF, Jacques. A história nova. São Paulo: Martins Fontes, 1998.

${ }^{10}$ LE GOFF, 1998, p. 16.

${ }^{11}$ Cf. BAKHTIN, M. A cultura popular na Idade Média e no Renascimento: o contexto de François Rabelais. São Paulo: Hucitec, 1999.

12 Cf. LE GOFF, J. Os intelectuais da Idade Média. São Paulo: Brasiliense, 1988. p. 50.

13 LE GOFF, 1988, p. 54. 
Logo, muito menos o papa possui a plenitude do poder nas coisas espirituais, pois na pessoa dos apóstolos foi interdito ao papa e aos demais prelados exercer sobre os fiéis, em quaisquer assuntos, tanto poder quanto os reis e príncipes exercem sobre seus súditos ${ }^{14}$.

Como ilustração, cabe aqui o caso de Orleans, em 1022 d.C., quando 14 clérigos da alta hierarquia foram queimados por questionarem a graça do batismo, a eucaristia, a remissão dos pecados mortais e outros pontos importantes do cristianismo medievo. ${ }^{15}$ É necessário lembrar, também, dos cátaros, dos valdenses, Wycliffe, Huss e Savonarola.

Lutero foi uma ponta do iceberg, favorecido pelos contextos social, cultural, econômico e religioso propícios para o desencadeamento de ondas transformadoras iniciadas na Europa e expandidas para todo o mundo, criando não somente novos cristianismos, mas também outras formas de pensar a vida e o ser humano na arte, na política, na economia, entre outros. ${ }^{16}$

A partir dessas constatações, percebe-se que a escrita da história, por vezes, é injusta e silencia vozes importantes e significativas. Por isso é necessário lembrar que a Reforma não é somente a história de Lutero, Calvino, Zwínglio etc., como, também, movimentos posteriores devem ser levados em consideração, mesmo aqueles que são tratados com desconfiança. Por isso não é adequado simplesmente afirmar o princípio sola scriptura sem levar em consideração figuras como Tomas Müntzer e os anabatistas, os quais representam propostas de aproximação à Bíblia. Esses podem nos servir de crítica ao que se estabeleceu como "somente as Escrituras" na ortodoxia luterana e abrir novos caminhos já traçados em nossas "origens".

\section{Sola scriptura e a ortodoxia protestante}

A atitude de Lutero de ouvir a Palavra (fides ex auditu) - "não fiz nada. Deixei a Palavra agir" - estremeceu o papado e o império. ${ }^{17} \mathrm{O}$ movimento de volta às fontes (ad fontes!), na esteira do humanismo (elite) ${ }^{18}$ permitiu redescobrir e desenvolver doutrinas bíblicas que se chocaram com a tradição e com o magistério da Igreja Católica. Para Lutero, “a Bíblia era 'o livro do Espírito Santo’, ‘o veículo do Espírito’,

${ }^{14}$ OCKHAM, G. Brevilóquio sobre o principado tirânico. Petrópolis: Vozes, 1988. p. 54.

${ }^{15}$ Cf. BARROS, José D’Assunção. Papas, imperadores e hereges na Idade Média. Petrópolis: Vozes, 2012.

${ }^{16}$ Berman descreve o impacto da Reforma sobre a tradição legal do Ocidente, que não somente seria perceptível no passado, "mas também influencia o presente e o futuro". Cf. BERMAN, H. Law and Revolution II: The Impact of the Protestant Reformations on the Western Legal Tradition. Harvard: Harvard University Press, 2006, p. xii. Cf. também BERMAN, 2006, p. 29-78.

${ }^{17}$ Cf. GEORGE, 1994, p. 56.

${ }^{18}$ De acordo com Timothy George, o humanismo foi um "movimento de reforma que se originou com a elite intelectual da Europa, tendo sido dominado por ela [...]. Ad fontes! - de volta às fontes! - era o mote dos estudiosos humanistas, cujo trabalho abriu novas perspectivas na história, na literatura e na teologia". E continua: "o Humanismo influenciou profundamente todas as ramificações da Reforma" (GEORGE, 1994, p. 18). 
não apenas suas palavras, mas até suas frases são inspiradas; mesmo sendo escritas por homens, não são nem veem de homens, mas de Deus"19. Ele e outros reformadores enfatizavam o caráter dinâmico da Bíblia. As passagens bíblicas eram consideradas eventos vivos, aqui e agora. O Espírito vivifica! Assim, é possível "sentir" as palavras da Escritura "no coração". Está claro que a experiência é necessária para entender a Palavra. ${ }^{20}$ Mas a forma como essa palavra é acolhida no coração ganhou contornos bem definidos pela Reforma Magisterial, especialmente por meio da pregação no culto, que recebe novo status nessa ala da Reforma.

A igreja não seria a "casa da escrita", dizia Lutero, mas a "casa da fala". Por isso o sermão passou a ser o núcleo da liturgia. Na Confissão de Augsburgo (artigo 5) estaria representada a teologia luterana da palavra (pregação), por meio da qual se recebe a fé justificadora. Para Bayer, a confissão "condenando uma compreensão direta e imediata - 'entusiasta' - do Espírito Santo, insiste que Deus vem no verbum externum, na 'palavra física'"21. Essa redução à palavra física (meios externos) colocava a ortodoxia luterana em rota de colisão com a subjetividade moderna e com o misticismo. ${ }^{22}$ Combinado com o esforço para evitar a suficiência das obras para a salvação, Lutero e outros suprimiram a experiência interior com o Espírito ou relegaram-na a segundo plano. Ficou o estigma de que os espiritualistas relativizavam a Bíblia e a palavra pregada, devendo ser combatidos.

$\mathrm{O}$ excesso de reduzir o Espírito à letra da Escritura tirou-lhe a autonomia, reservando à Terceira Pessoa da Trindade um papel funcionalista de garantir o conteúdo e a mensagem da Escritura. ${ }^{23}$ A ortodoxia protestante (especialmente a luterana) identificou dois extremos. De um lado, o grupo que foi chamado de "entusiastas", sobre o qual pesava a acusação de enxergar o Espírito livre inclusive das Escrituras; de outro, os católicos, que mantinham o Espírito sob as leis eclesiásticas e doutrinais. As formas encontradas para lidar com esses extremos foram os credos e as fórmulas confessionais, consideradas suficientes para encerrar as controvérsias do período pós-Reforma. ${ }^{24}$

Ao Espírito restou agir no coração do crente por meio de "palavras vivas", a pregação da Palavra, de tal forma que Espírito Santo e fé se equivaliam. Viver no Espírito era entendido como viver pela fé, em uma clara simultaneidade entre Espírito e letra. ${ }^{25}$ Mas essa ação divina é extremamente melindrosa, pois, como afirma Ezequiel Hanke, "tanto a letra da doutrina, do papa, de um reformador, de um ministro da igreja, ou de qualquer pessoa, quanto a experiência do pietismo, do pentecostalismo

19 Cf. GEORGE, 1994, p. 83.

${ }^{20}$ Cf. GEORGE, 1994, p. 84.

${ }^{21}$ BAYER, Oswald. A teologia de Martim Lutero: uma atualização. São Leopoldo: Sinodal, 2007. p. 180.

${ }^{22}$ Cf. OLIVEIRA, David Mesquiati. A pneumatologia de Lutero: uma aproximação. Revista Reflexus, v. 11, n. 17, 2017 e AULÉN, Gustav. A fé cristã. 2. ed. São Paulo: ASTE, 2002. p. 299-300.

${ }^{23}$ BRANDT, Hermann. O Espírito Santo. 2. ed. São Leopoldo: Sinodal, 1985. p. 13.

${ }^{24}$ Cf. BRANDT, 1985, p. 14.

${ }^{25}$ BAYER, Oswald. Viver pela fé: justificação e santificação. São Leopoldo: Sinodal, 1997. p. 57. 
ou do carismatismo, podem matar e asfixiar a ação do Espírito no crente"26. Essa subjetividade é característica da Modernidade, que enfatizou a dimensão direta do sujeito, possibilitando-lhe descobrir "como nunca antes seu caráter único e sua liberdade. Mais e mais arrancado das amarras tradicionais e das mediações institucionais, ele está diretamente diante de Deus. Essa imediaticidade de Deus é vivenciada no próprio interior"'27.

Bernd Hilberath afirma que:

Desde o início as comunidades cristãs, depois a grande igreja em formação e, após o cisma de fé, as igrejas confessionais sentiram, cada uma à sua maneira, como perturbadores e perigosos os movimentos entusiastas e carismáticos (p. ex., montanistas, adeptos de Joaquim de Fiore, movimentos batistas, quacres, igrejas pentecostais) que invocavam o Espírito. Em face da suposta alternativa: "tumulto ou ordem", ocorreram uma ampla domesticação e institucionalização do Espírito Santo. Assim, diferentemente do âmbito da Igreja Ortodoxa, "a doutrina ocidental do Espírito não se tornou em primeiro lugar uma doutrina sobre o Espírito, mas sobre sua administração pela igreja" [...]. As consequências desse desenvolvimento foram: reserva de experiências "autênticas" do Espírito para a igreja dos primeiros tempos, redução da atuação atual do Espírito à vida interior do indivíduo, crescente dualismo entre espírito e matéria em virtude de uma intelectualização do discurso sobre o Espírito ${ }^{28}$.

Esse “embaraço pneumatológico" não foi resolvido nos tempos da Reforma, senão que, pelo contrário, acentuou-se e prevaleceu a desconfiança e um consequente fechamento posterior na "reta doutrina". Uma tentativa de abertura nessa ortodoxia teria ocorrido em terreno alemão no século seguinte (XVII), com o que ficou conhecido como movimento pietista. Contudo, as contribuições dos radicais durante o século XVI ainda carecem de abordagens aprofundadas.

\section{A Reforma Radical e a leitura bíblica}

A Reforma Radical não foi simplesmente uma "ala" da Reforma do século XVI ou "um efeito colateral que revelou apenas a forma mais extrema da Reforma; antes, foi um movimento que gerou nova forma de fé e vida cristãs" 29 . Buscando fazer uma apresentação geral da Reforma Radical, Timothy George afirma:

A Reforma radical foi um tremendo movimento de renovação espiritual e eclesiástica que ficou à margem das importantes igrejas territoriais, a católica e a protestante, durante a grande convulsão religiosa do século XVI. Entretanto, esse movimento não foi

${ }^{26}$ HANKE, Ezequiel. O Espírito Santo na teologia de Lutero e Calvino. 2015. Dissertação (Mestrado) Faculdades EST, São Leopoldo, 2015. p. 21.

27 BENKE, Christoph. Breve história da espiritualidade cristã. Aparecida: Santuário, 2011. p. 152.

${ }^{28}$ HILBERATH, Bernd Jochen. Pneumatologia. In: SCHNEIDER, Theodor (Org.). Manual de dogmática. 2. ed. Petrópolis: Vozes, 2002. v. 1, p. 404.

29 GEORGE, 1994, p. 254. 
nem marginal nem periférico em seus direcionamentos básicos e vitalidades espirituais. Englobando tanto o ecumenismo quanto o sectarismo, tanto a revolução violenta quanto o comunalismo pacifista, sublimando os impulsos ascéticos, místicos e racionalistas da baixa Idade Média, a Reforma radical, considerada como entidade, apresentou uma crítica completa ao corpus christianum em suas principais mutações protestante e católica romana ${ }^{30}$.

Ainda de acordo com T. George, no caso dos anabatistas, a radicalidade era expressa na ênfase na leitura da Bíblia, especialmente do Novo Testamento, e no anseio por restaurar a pureza da igreja apostólica. No caso dos espiritualistas, a radicalidade residia na experiência interior do Espírito, visto que não estavam muito preocupados com a "igreja externa", chegando, em alguns casos, a abrir mão das externalia, como o batismo e mesmo a Ceia. Entre os racionalistas evangélicos prevalecia a razão, não uma razão autônoma iluminista, mas uma razão informada pelo Espírito e pelas Escrituras, que questionava muitos dogmas e a tradição da igreja antiga. ${ }^{31}$ A relação entre o Espírito e as Escrituras é um tema comum que perpassa de forma especial esse grupo. Dessa forma, podemos afirmar que a Reforma Radical, enquanto parte integrante do movimento da Reforma, apresenta peculiaridades quanto ao princípio do sola scriptu$r a$, que desenvolveremos mais tarde.

Um dos princípios da Reforma é a centralidade das Escrituras, o que para Foucault seria o germe da crítica. Segundo ele, para compreender a história da crítica é preciso ancorá-la na crítica bíblica. Com a busca pela autêntica revelação das Escrituras, não mais governada pelo magistério da igreja, cria-se a possibilidade de descortinar o que verdadeiramente estava nas sagradas letras, mesmo desqualificando a interpretação da tradição. Por isso Foucault pode afirmar que "a crítica é historicamente bíblica" 32 . No sola scriptura, a crítica à tradição é o germe do fazer crítico, o que significou importante contribuição, segundo o autor, do que seriam as críticas modernas.

A centralidade da Escritura e todas as fortificadas afirmações teológicas de inspiração já indicam como sua presença na piedade dos reformadores é determinante e descentraliza outros poderes eclesiásticos (pelo menos em termos ideais). Por isso Calvino, no século XVI, condenava como erro perniciosíssimo a valoração da Escritura segundo os alvitres da igreja:

Entre a maioria, entretanto, tem prevalecido o erro perniciosíssimo de que o valor que assiste à Escritura é apenas até onde os alvitres da Igreja concedem. Como se de fato a eterna e inviolável verdade de Deus se apoiasse no arbítrio dos homens! Pois, com grande escárnio do Espírito Santo, assim indagam: "Quem porventura nos pode fazer crer que essas coisas provieram de Deus? Quem, por acaso, nos pode atestar que elas chegaram até nossos dias inteiras e intactas? Quem, afinal, nos pode persuadir de que

\footnotetext{
30 GEORGE, 1994, p. 252.

${ }^{31}$ Cf. GEORGE, 1994, p. 254.

${ }^{32}$ FOUCAULT, M. The Politics of Truth. New York: Semiotext(e), 1997. p. 46.
} 
este livro deve ser recebido reverentemente, excluindo um outro de seu número, a não ser que a Igreja prescrevesse a norma infalível de todas essas coisas?" 33 .

A Escritura, nesse sentido, deixa de ser artefato da instituição e torna-se instrumento de intervenção e crítica (Foucault). Contudo, como a Bíblia seria utilizada ou lida? Ainda pensando nas margens da história, outros movimentos de reforma podem contribuir para os mecanismos de acesso e interpretação das Sagradas Escrituras, os quais podem ativar de maneira mais intensa sua potencialidade crítica, valorizando a participação do leitor na vivência da Escritura. Nesse ponto, Tomás Müntzer e a Reforma Radical ${ }^{34}$ podem ser inseridos, mesmo tratados com tanto preconceito por conta da força revolucionária de sua teologia e alguns de seus princípios. ${ }^{35} \mathrm{O}$ que chamamos aqui de Reforma Radical segue a descrição de G. Williams:

Esta Reforma Radical foi um amontoamento, não muito integrado, de Reformas e restituições doutrinárias e instituições subscritas por anabatistas de vários tipos, por espiritualistas e espiritualizantes de diversas tendências (desde Tomás Müntzer, passando pelo Grübler individualista Sebastián Franck, até o quietista e pietista Gaspar Schwenckfeld, assim como pelos racionalistas evangélicos, para quem a única base essencial era o Novo Testamento (desde Juan de Valdés, passando por Lelio Socino, até Pedro Gonesius) $)^{36}$.

Interessante, Müntzer e os Radicais, desde as discussões com Lutero e demais reformadores, foram alvos de avaliações conservadoras, a ponto de serem tratados como fanáticos, possuídos pelo demônio e desdenhadores das Escrituras. ${ }^{37}$ Contudo, seria mais adequado afirmar que Müntzer era porta-voz de uma espiritualidade revolucionária e militava por uma hermenêutica do Espírito.

Ademais, segundo sua própria confissão, havia aceitado a hermenêutica espiritualista dos mesmos storchitas, segundo a qual os dois Testamentos, o Antigo e Novo, deveriam ser interpretados no Espírito [...] No manifesto de Praga, Müntzer defende que a meta da redenção é o recebimento dos sete dons do Espírito Santo em forma de visões, sonhos, afirmações extáticas e exegeses inspiradas. ${ }^{38}$

Os radicais diferenciavam Palavra e Escritura de uma maneira muito peculiar, evocando a ideia de Palavra exterior e interior. A primeira seria vista de muitas formas, podendo se referir ao texto bíblico escrito, na maneira como está traduzido nas línguas autóctones; por vezes era vista como a Palavra audível e visível nos sermões

33 CAlvinO, J. As Institutas ou Tratado da Religião Cristã (edição clássica). Tradução Waldyr Carvalho Luz. São Paulo: Casa Editora Presbiteriana, 1985. v. 1, p. 81.

34 Lutero chamava-os de Schwärmer.

35 Para discussão a respeito de Müntzer e a Reforma Radical, cf. WILLIAMS, 1983 e BLOCH, 1973.

36 WILLIAMS, 1983, p. 6.

37 Cf. WILLIAMS, 1983, p. 69-79.

38 WILLIAMS, 1983, p. 70. 
ou sacramentos; ou, também, poderia ser a Palavra encarnada, o Verbo, a saber, o Jesus histórico.

A Palavra interior, por sua vez, da mesma forma possui vários sentidos: abismo interior, confundido com a consciência ou a divina Palavra que está no interior do ser humano. Para Müntzer, cada crente é templo do Espírito, e no seu interior há a Palavra, sem a qual ninguém pode falar de maneira inspirada ou expressar algo verdadeiro acerca de Deus. ${ }^{39}$ Essa perspectiva poderia confundir a "Palavra interior" e o "Espírito Santo". Contudo, os radicais se esmeraram por fazer a devida distinção:

A Palavra e o Espírito Santo no interior de cada indivíduo parecem, por vezes, confundir-se. Contudo, há o esforço para distingui-los. O papel da Palavra interior é dar luz; por sua vez, a do Espírito Santo é impulsionar a vontade. Mas, na verdade, o Espírito vem a ser um modo da Palavra. Esta Palavra é a luz divina no interior de cada indivíduo (Jo 1.9), consubstancial com Deus ${ }^{40}$.

Os radicais acreditavam na centralidade da Palavra de Deus para a piedade cristã. Eles não negavam as Escrituras, como alguns os acusam, mas valorizavam o que eles chamavam de Palavra Interna. Por mais subjetivista que pareça ser, esse conceito é um complexo e interessante princípio hermenêutico pneumatológico, o que poderia ser aproximado ao que alguns pesquisadores chamarão, hoje em dia, de hermenêutica pentecostal. ${ }^{41}$ Essa Palavra interior proporcionava possibilidades de compreensão da Escritura e seus sentidos, os quais eram partilhados e disputados em grupo. ${ }^{42}$ Aqui, aponta-se para uma leitura bíblica na qual a relação entre o texto (exterior) e o indivíduo/comunidade (interior) tem seu lugar. Encontramos, então, o princípio da sola scriptura em uma perspectiva mais popular, porque não restringe o acesso à Bíblia aos especializados da filologia ou análise histórica, mas valoriza a potencialidade do receptor do texto, que possui em si instrumentos, através dos quais poderão interpretar as Escrituras, o que permite que até os mais iletrados tenham encontros salvíficos com o texto. Mesmo com todos os riscos previstos, a Bíblia entra na comunidade como instrumento de diálogo e inclusão. Como texto vivo, o texto bíblico dialogará com as subjetividades de seus receptores no processo de significação, e permitirá que os leitores tenham muitas faces e classes, sem que isso seja desqualificado por posturas elitistas. A Bíblia continua o centro, mas é permitido encontrar no receptor e seus dilemas instrumentos para animação da fé e resposta às questões concretas da vida.

Aqui entra a importância de tratar a Palavra como "viva", capaz de atuar de forma pessoal com o crente. $\mathrm{O}$ entendimento de Lutero sobre a palavra "viva" estava restrito à pregação, à Escritura falada. Para os espiritualistas, o Espírito também tinha a liberdade de agir para além da letra e da pregação, tendo no mais íntimo do ser hu-

${ }^{39}$ Cf. WILLIAMS, 1983, p. 907.

40 WILLIAMS, 1983, p. 908.

${ }^{41}$ Cf. ARCHER, Kenneth J. A Pentecostal Hermeneutic. Spirit, Scripture and Community. Cleveland, Tennessee USA: CPT Press, 2005.

${ }^{42}$ Cf. WILLIAMS, 1983, p. 913. 
mano (para recordar os místicos) e na vida em comunidade as condições necessárias para atuar.

Guardadas as devidas proporções, essas intuições apontam para projetos de acesso à Bíblia - legitimamente reformados - através dos quais a polissemia dos textos e as experiências da comunidade receptora contribuem para pensarmos o como da centralização da Escritura na igreja. Além disso, essa postura interpretativa antecipa perspectivas em relação ao texto que podem se aproximar das novas perspectivas hermenêuticas.

\section{Avaliação da leitura radical: proposta de leitura da Bíblia}

A Bíblia só pode tornar-se centro da igreja se a vida for parte do processo de significação e compreensão do texto. E pelo que temos mostrado, a experiência como mediadora e iluminadora da interpretação da Escritura também tem lugar na tradição dos movimentos da Reforma. Inclusive, isso representa valorização da vida do receptor, suas subjetividades e vicissitudes.

Nesses últimos anos, tem ficado claro que não importa se somos metodologicamente refinados ou não, o consumo de textos e suas leituras sempre serão criativos. Essa afirmação está inserida na disputa entre a valorização do "autor", "texto" ou "leitor" nos projetos de interpretação: intentio auctoris, intentio operis e intentio lectoris.

Umberto Eco sintetiza bem essas discussões:

[...] o debate clássico articulava-se, antes de mais nada, em torno da oposição entre estes dois programas:(a) deve-se buscar no texto aquilo que o autor queria dizer; (b) deve-se buscar no texto aquilo que ele diz, independentemente das intenções do autor. Só com a aceitação da segunda ponta da oposição é que se poderia, em seguida, articular a oposição entre: (b1) é preciso buscar no texto aquilo que ele diz relativamente à sua própria coerência contextual e à situação dos sistemas de significação em que se respalda; (b2) é preciso buscar no texto aquilo que o destinatário aí encontra relativamente a seus próprios sistemas de significação e/ou relativamente a seus próprios desejos, pulsões, arbítrios ${ }^{43}$.

Em Obra aberta, Eco abre quase que irresponsavelmente as portas para a multiplicidade de interpretações, especialmente por contar com a criatividade do leitor. ${ }^{44}$ No entanto, dizer que um texto não tem $f i m^{45}$ não quer dizer que todo ato de interpretação tenha um final feliz. ${ }^{46}$ Por isso fala-se em equilíbrio entre leitor e fidelidade à obra literária. "Isso quer dizer que o texto interpretado impõe restrições a seus intérpretes. Os limites da interpretação coincidem com os direitos do texto (o que não quer dizer

${ }^{43}$ ECO, Umberto. Os limites da Interpretação. 2. ed. São Paulo: Perspectiva, 2004. p. 6-7.

${ }^{44}$ Cf. ECO, Umberto. Obra aberta: forma e interdeterminação nas poéticas contemporâneas. 9. ed. São Paulo: Perspectiva, 2013.

45 Tem diversas possibilidades de sentido.

${ }^{46}$ Cf. ECO, Umberto. Interpretação e Superinterpretação. São Paulo: WMF Martins Fontes, 2012. p. 28. 
que coincidem com os direitos de seu autor) ${ }^{\prime 47}$. Outra tentativa seria reconfigurar o significado dos conceitos, migrando, como fizeram as ciências da narrativa, para o leitor e autor implícitos, sem perder de vista as relações que o texto tem com as dinâmicas intertextuais e em seus efeitos. ${ }^{48}$

Para a perspectiva que valoriza o receptor, é fundamental o diálogo com o horizonte de expectativas dos leitores, o lugar onde se consome a obra. ${ }^{49}$ Isso segue de perto as intuições de Lotman quando desenvolve a segunda função do texto. Para Lotman, o texto tem três funções: 1 . função comunicativa; 2 . função geradora de sentido; 3. função mnemônica. ${ }^{50}$ A primeira função mostra o texto como processo de realização da língua natural; na segunda perspectiva, o texto é um potente instrumento de geração de sentidos. Para Lotman, o texto preserva potencialidades de sentidos que poderão ser acessadas em tempos posteriores ao original: quanto mais lido, mais rico fica o texto. Não há nessa perspectiva de leitura ingenuidades tais como "isenção de interesses" ou "deslocamento do contexto do leitor", como se a leitura fosse feita no "ar" ou em regiões celestiais, ou, até mesmo, como se ler significasse o esgotamento do texto no passado. Por isso sempre a leitura será engajada, pois os dilemas das comunidades leitoras serão instrumentos para formulação de perguntas, denunciarão ocultamentos e alimentarão movimentos contextualizados.

A Bíblia é texto vivo. Seus símbolos, metáforas e estruturas mais básicas estão carregados com forças de sentidos, as quais ganham potência na leitura na comunidade de fé, que é formada por pessoas com suas experiências. Assim, as perguntas contextuais e as questões nas quais os pés das comunidades tocam poderão ser o lugar privilegiado para a compreensão da Bíblia. Talvez essa perspectiva poderia ser interpelada com a afirmação de que assim não há limites para a interpretação e até mesmo as leituras violentas ganhariam espaço. Contra essa afirmação pode-se afirmar que leitura eivada de interesses não é uma opção, mas um dado que há muito as ciências da linguagem e hermenêutica denunciaram. Nesse sentido, as subjetividades, a história, os gritos, o sangue, as questões, os dilemas, os mundos, a linguagem, os sonhos e os desejos do receptor não podem ser evitados, mas precisam ser canalizados pelos interesses da promoção da vida. Isso fará da Bíblia uma parceira de diálogo e construção de sentido. Além disso, não é justo dizer que a leitura não terá limites. Pelo contrário, a realidade e vida da comunidade não somente nortearão os sentidos, como também os limitarão. Aliás, o próprio texto, como diz Eco, tem seus limites e apontamentos interpretativos. Outra coisa, os pressupostos do Reino e sua justiça determinarão os limites dos interesses teológicos das leituras, o que impedirá qualquer espaço para interpretações desumanizadoras.

${ }^{47}$ ECO, 2004, p. XXII.

${ }^{48}$ Cf. PRINCE, Gerald. Narratology. The Form and Functioning of Narrative. Berlin; Amsterdam; New York: Mouton Publishers, 1982.

49 Cf. JAUSS, H. R. A História da Literatura como provocação à Teoria Literária. São Paulo: Ática, 1994. p. 23-28.

${ }^{50}$ Cf. LOTMAN, I. Por uma teoria semiótica da cultura. Belo Horizonte: FALE/UFMG, 2007. 
Dessa forma, munidos das preocupações próprias da vida da comunidade e a capacidade de interação entre leitor(es)/leitora(as) e texto, a Bíblia será instrumento de transformação e norteará a caminhada de fé. Consequentemente, a releitura e recepção do texto bíblico, que realmente significam sua popularização, sairão das mãos dos “donos do saber” para ganhar vida na partilha, onde há a presença do Espírito acolhido na comunidade.

Mesquiati de Oliveira, nessa mesma linha, partindo do diálogo com o movimento da Reforma em seu sentido amplo (magisterial, radical e católica), defende que além dos quatro solae da Reforma Luterana, um quinto princípio igualmente exclusivo e correlato deveria ser enfatizado, na esteira dos reformadores radicais - e que no entendimento do Mesquiati é também a característica do pentecostalismo, especialmente o chamado pentecostalismo clássico - que seria o solus Spiritus Sanctus. ${ }^{51}$ Sem essa ação direta do Espírito Santo, tanto no coração do indivíduo como no seio da comunidade, a leitura e a acolhida das Escrituras estariam comprometidas. Assim, não existiria o sola scriptura sem o solus Spiritus. Essa chave pneumatológica é não só potencializadora de sentido como também é necessária para o vivo entendimento das Escrituras. ${ }^{52}$

A hermenêutica do Espírito da Reforma Radical é um patrimônio para o cristianismo. Quando grupos como os pentecostais a acionam, estão retomando, em grande medida, a tradição da Reforma do século XVI. No entanto, a desconfiança para com o Espírito Santo - e para com os grupos que afirmam ter experiências diretas com ele - resiste, seja nos escritos acadêmicos ou mesmo nos círculos das igrejas, dado o modus operandi dos grupos espiritualistas naquele tempo, seus excessos e seus erros. Mas não são somente seus equívocos que devem ser descritos, mas também seus insights. É tempo de as teologias e as igrejas serem capazes de incorporar essas contribuições da Reforma de maneira mais articulada e enriquecedora, abrindo-se para outras vias, de forma consciente e deliberada. Como afirmou Timothy George, além de ser um movimento histórico, a Reforma deve ser vista "como movimento do Espírito de Deus" e, assim, "possui um significado permanente para a igreja de Jesus Cristo" "53. Estabelecer um diálogo com a história desses grupos da Reforma e com os novos espiritualistas de nosso tempo pode ser mutuamente enriquecedor. Mas teria que ser um diálogo franco, aberto e propositivo, que fosse capaz de desinstalar-nos, de tirar-nos de nossas cômodas posições e pressupostos.

51 Cf. OLIVEIRA, 2017.

${ }^{52}$ Kenner Terra mostra como a experiência do Espírito foi marcante na igreja das origens. Cf. TERRA, Kenner. Êxtase, pentecostes e unidade: desafios à luz das origens. In: OLIVEIRA, David Mesquiati (Org.). Pentecostalismos e unidade. São Paulo: Fonte Editorial; FPLC; RELEP, 2015. p. 167-179. Donald Dayton, por sua vez, afirmou que essa ação narrada em Atos pode ter se tornado paradigmática para a igreja, possibilitando novas apropriações ao longo dos séculos. Cf. DAYTON, Donald. Theological roots of Pentecostalism. Peabody, Massachusetts: Hendrickson, 1991.

${ }^{53}$ GEORGE, 1994, p. 306. 


\section{Conclusão}

À luz da leitura bíblica da Reforma Radical, ler a Bíblia historicamente não pode somente significar inseri-la no seu contexto histórico original, mas precisa levar em consideração o receptor historicamente instalado. Nesse sentido, a afirmação "somente a Escritura" precisa ser sucedida pela questão "como isso se aplicará?". Em um contexto de luta crítica pela capacidade de compreensão para além da tradição e magistério, busca-se a verdade da Escritura, à qual se entende ser possível acessar sem que sistemas ou organizações influenciem. Essa postura sempre correrá o risco de ser "elitização da interpretação" e acreditará nas inocentes afirmações do paradigma do sujeito, que nega as subjetividades, intuições, sensibilidades e mediações. Inclusive, essas características, por vezes negadas, são o caminho possível para que a Palavra de Deus se encarne na vida daqueles e daquelas que não somente a leem, mas vivem-na nas lutas pessoais, performatizam-na nas celebrações e consubstanciam-na na relação consigo mesmo, com o outro e com Deus.

Como consequência dessas discussões, precisamos levar em consideração que o contexto original, antes de qualquer coisa, é uma narrativa construída pelo intérprete especializado ou não, o qual acredita ser capaz de reconstruir e descrever a realidade. Portanto o histórico da Bíblia Sagrada é também o lugar de leitura, porque esse tem potencialidade para determinar sua expressão de sentido. O lugar do receptor determina as perguntas e, consequentemente, conduz suas respostas. Dessa forma, os dilemas da vida da igreja, com todos os seus interesses por justiça, libertação, promoção e sinalização do Reino, são parte prioritária no projeto de consumo da Escritura.

Assim, a Reforma Radical - que é parte, por vezes marginalizada, do movimento estabelecido desde a Reforma Protestante Magisterial e que contribui na construção da identidade do protestantismo e demais movimentos neles enraizados - pode ser resgatada como fonte para intuições hermenêuticas, através das quais se responde à questão de como a Bíblia pode ser o centro da piedade e caminhada de fé.

\section{Referências}

ALTMANN, Walter. Lutero e libertação. São Leopoldo: Sinodal; São Paulo: Ática, 1994. ARCHER, Kenneth J. A Pentecostal Hermeneutic. Spirit, Scripture and Community. Cleveland, Tennessee USA: CPT Press, 2005.

AULÉN, Gustav. A fé cristã. 2. ed. São Paulo: ASTE, 2002.

BAKHTIN, M. A cultura popular na Idade Média e no Renascimento: o contexto de François Rabelais. São Paulo: Hucitec, 1999.

BARROS, José D’Assunção. Papas, imperadores e hereges na Idade Média. Petrópolis: Vozes, 2012.

BAYER, Oswald. A teologia de Martim Lutero: uma atualização. São Leopoldo: Sinodal, 2007. BAYER, Oswald. Viver pela fé: justificação e santificação. São Leopoldo: Sinodal, 1997.

BENKE, Christoph. Breve história da espiritualidade cristã. Aparecida: Santuário, 2011.

BERMAN, H. Law and Revolution II: The Impact of the Protestant Reformations on the Western Legal Tradition. Harvard: Harvard University Press, 2006.

BLOCH, E. Tomás Müntzer: teólogo da revolução. Rio de Janeiro: Tempo Brasileiro, 1973. 
BRANDT, Hermann. O Espírito Santo. 2. ed. São Leopoldo: Sinodal, 1985.

BURKE, Peter. Origens da história cultural. Variedades de história cultural. São Paulo: Civilização Brasileira, 2006.

BURKE, Peter. O que é história cultural? Rio de Janeiro: Zahar, 2008.

CALVINO, J. As Institutas ou Tratado da Religião Cristã (edição clássica). Tradução Waldyr Carvalho Luz. São Paulo: Casa Editora Presbiteriana, 1985. v. I.

DAYTON, Donald. Theological roots of Pentecostalism. Peabody, Massachusetts: Hendrickson, 1991.

ECO, Umberto. Interpretação e Superinterpretação. São Paulo: WMF Martins Fontes, 2012.

ECO, Umberto. Obra aberta: forma e interdeterminação nas poéticas contemporâneas. 9. ed. São Paulo: Perspectiva, 2013.

ECO, Umberto. Os limites da Interpretação. 2. ed. São Paulo: Perspectiva, 2004.

FOUCAULT, M. The Politics of Truth. New York: Semiotext(e), 1997.

GEORGE, Timothy. Teologia dos reformadores. São Paulo: Vida Nova, 1994.

HANKE, Ezequiel. O Espírito Santo na teologia de Lutero e Calvino. 2015. Dissertação (Mestrado) - Faculdades EST, São Leopoldo, 2015.

HILBERATH, Bernd Jochen. Pneumatologia. In: SCHNEIDER, Theodor (Org.). Manual de dogmática. 2. ed. Petrópolis: Vozes, 2002. v. 1, p. 403-497.

JAUSS, H. R. A História da Literatura como provocação à Teoria Literária. São Paulo: Ática, 1994.

LE GOFF, J. A História Nova. 4. ed. São Paulo: Martins Fontes, 1998.

LE GOFF, J. Os intelectuais da Idade Média. São Paulo: Brasiliense, 1988.

LOTMAN, I. Por uma teoria semiótica da cultura. Belo Horizonte: FALE/UFMG, 2007.

OCKHAM, G. Brevilóquio sobre o principado tirânico. Petrópolis: Vozes, 1988.

OLIVEIRA, David Mesquiati. A pneumatologia de Lutero: uma aproximação. Revista Reflexus, v. 11, n. 17, 2017.

PESSAVENTO, Sandra. História e linguagens. Rio de Janeiro: 7 Letras, 2006.

PRINCE, Gerald. Narratology. The Form and Functioning of Narrative. Berlin; Amsterdam; New York: Mouton Publishers, 1982.

RIOUX, Jean-Pierre; SIRINELLI, Jean-François (Orgs.). Para uma história cultural. Lisboa: Estampa, 1998.

TERRA, Kenner. Êxtase, Pentecostes e unidade: desafios à luz das origens. In: OLIVEIRA, David Mesquiati (Org.). Pentecostalismos e unidade. São Paulo: Fonte Editorial; FPLC; RELEP, 2015. p. 167-179.

WILLIAMS, George H. La Reforma Radical. México: Fondo de Cultura Económica, 1983. 